\section{ECONOMICS}

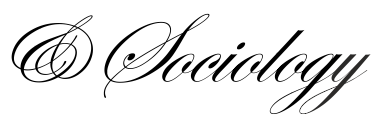

Aali-Bujari, A., Venegas-Martínez, F., \& García-Santillán, A. (2019). Schooling levels and wage gains in Mexico. Economics and Sociology, 12(4), 74-83. doi:10.14254/2071-789X.2019/12-4/4

\title{
SCHOOLING LEVELS AND WAGE GAINS IN MEXICO
}

\author{
Alí Aali-Bujari, \\ Universidad Autónoma de Estado \\ de Hidalgo, México \\ E-mail:alibujari@yahoo.es \\ Francisco Venegas- \\ Martínez, \\ Instituto Politécnico Nacional, \\ México \\ E-mail: \\ fvenegas1111@yahoo.com.mx
}

\begin{abstract}
Arturo García-Santillán, Universidad Cristóbal Colón, México

E-mail:agarcias@ucc.mx
\end{abstract}

Received: March, 2019

1st Revision: June, 2019

Accepted: November, 2019

DOI: $10.14254 / 2071-$

789X.2019/12-4/4

JEL Classification: I26, C13, I23
ABSTRACT. This paper assesses the impact of the returns to education on income of the heads of family in Mexico in 2016. The analysis is based on Mincer's (1974) earnings function by using microdata from the National Household Income Survey (ENIGH acronym in Spanish) 2016. Estimations following Mincer equation are carried out by levels of schooling. The main conclusion is that as the level of education among Mexican heads of family increases, it magnifies the increase in income levels, which, in turn, enlarges human capital and learning capacity needed for sustained growth and welfare.

\section{Introduction}

Most of the research on education, theoretical and/or empirical, is related to economic growth or economic development. The theory of human capital emphasizes that education is an investment that increases future income for individuals and for society as a whole. It has been shown in a large number of empirical investigations that investing in education generates greater productivity and quality of the workforce: see, for instance, Schultz (1961) and Becker (1975), Heckman (2005), Hugget, Ventura and Yaon (2006), Christiansen, Joensen and Nielsen (2007), Su and Lu (2016), and many others. Most of research indicates that the majority of countries with high average schooling levels enjoy high levels of per capita income. In this regard, education contributes to raising productivity, earnings, and welfare for workers, which, in turn, has a positive impact on both firms and society. Most of the specialized literature regarding returns to education has found empirical evidence of positive returns. However, returns to education by levels of schooling need to be studied with 
a deeper concern since it constitutes one of the key factors for increasing human resource development and learning capacity necessary for sustained growth, which allows reaching better levels of growth and welfare. In this regard, investigations related to human capital investment, education attainments, and training can be found in Blundell et al. (1999), Psacharopoulos and Patrinos (2004), Psacharopoulos (1994), and Nafukho et al. (2004).

This paper addresses the impact of the returns to education by levels of schooling on income of the heads in Mexico as of 2016. The analysis is based on the Mincer's (1974) earnings equation by using data from the National Household Income Survey (Encuesta Nacional de Ingresos y Gastos de los Hogares, ENIGH) 2016, which is carried out with a biennial periodicity (every 2 years). The ENIGH 2018 is not yet available. Estimation of Mincer's equation will be carried out by levels of schooling.

The paper is organized as follows: section 2 presents a short review of the literature emphasizing onMexican data; section 3 provides data description; section 4 describes the econometric methodology to estimate Mincer's earnings function with the microdata from the ENIGH 2016; section 5 estimates the returns to education of the family heads by levels of schooling in Mexico, and analyzes and discusses the empirical findings; finally, section 6 offers the conclusions.

\section{Literature review}

Su and Liu (2016) examine the determinants of economic growth in Chinese cities by using panel data in 1991-2010 focusing on the role of human capital and Foreign Direct Investment (FDI). These authors find that the growth rate of Gross Domestic Product (GDP) per capita is positively correlated with human capital. Moreover, FDI has a positive effect on the growth rate of GDP, and this effect is intensified by the endowment of human capital. The study suggests that human capital contributes to growth as a facilitator of technology transfer derived from FDI. Their results show evidence of the complementary effect of human capital and intense FDI in technology in firms is related to intense FDI in labor. On the other hand, Heckman (2005) studies the role of investment in human capital in China finding that current Chinese policies favor more investment in physical capital than investment in human capital, and favor more investment in urban human capital than investment in rural human capital. Thus, an appropriate approach has to look for balances between investments in urban, rural and capital types.

Education is often considered as a factor in reducing inequality; however, as Frankema and Bolt (2006) argue, inequity in access to education is also an element that drives inequality in income distribution. Likewise, Hugget, Ventura and Yaon (2006) study the relation of human capital with income heterogeneity by developing a human capital model that can replicate properties of the correct distribution of initial human capital and learning capacity. They state that differences in learning capacity are essential to produce an increase in the dispersion of income over the life cycle and these differences account for most of the variation in the present value of income among agents. Their results highlight the origin of the initial conditions.

In the specialized literature there are several works dealing with the performance of education and its returns; see, for example: Carnoy (1967), Mincer (1974), Griliches (1977), Bracho and Zamudio (1994) and (1995), Barceinas (2002), Giannelli and Monfardini (2003), Austria-Carlos and Venegas-Martínez (2011) and (2017), Aali-Bujari, Ortiz-Zarco and RiosBolívar (2013), Cellini and Chaudhary (2014), Denice (2015), Doyle and Skinner (2016), Austria-Carlos, Venegas-Martínez and Pérez-Lechuga (2018), and Fogarty and Hasegawa (2019). In particular, Giannelli and Monfardini (2003) analyze the effects of expected income of young adults with high school diploma. These authors study decisions to stay in parents' 
home or to form a new home. Also, they study the decisions of individuals to gain work experience or invest in university education. They estimate that the expected lifetime income of young people is crucial when studying and deciding whether residing with parents. Finally, they find that poor labor market opportunities discourage young people from working and induce them to continue their studies; the cost of housing also greatly influences the decision to work and to leave the paternal home.

On the other hand, Cellini and Chaudhary (2014) study the performance of education in the United States through the National Longitudinal Survey of Youth 1997 (NLSY97). These authors use fixed-effect models to control unobservable effects of students, and find that students enrolled in graduate programs associated with for-profit universities earn $4 \%$ return per year, compared to high school students the rate of return is slightly lower, although it is still positive. Denice (2015) examines the performance of education in the United States of America and carries out a vertical and horizontally stratification. By using data from the National Longitudinal Survey of Youth 1997, the author finds that holders of titles associated with for-profit universities receive lower hourly wages than holders of public or private nonprofit university titles. On the other hand, graduates of for-profit colleges earn incomes not significantly different from high school graduates; both students from for-profit and nonprofit universities find positive benefits.

Doyle and Skinner (2016) study the causal impact of post-secondary education by introducing measures based on location. They use data from the National Longitudinal Survey of Youth 1997, and implement a set of measures based on geographic variation to examining the impact of educational achievement on income. These authors find that an additional year of postsecondary educational accomplishment results in a $9.7 \%$ increase in annual income. They also find that there is greater impact on the accomplishment of postsecondary education in women.

It is also worth mentioning that Psacharopoulos (1989) provides a detailed review of the trends of the returns to education through cross-national evidence before 1989 in 27 countries. Likewise, Blanden (2013) carries out a research on mobility and returns to education in 42 countries around the world. Finally, Benavot (1989) presents a cross-national study considering education returns, gender, and economic development in 96 countries during the period 1960-1985.

With respect to more recent studies of the returns to education in several countries, we point out the following papers: Oreopoulosand and Petronijevic (2013), Hout (2012) and Carneiro et al. (2011) deal with the returns to education for the USA; Arild et al. (2010) explore the impact of a mandatory education reform as well as pre-reform availability of schools above the mandatory level, on educational attainment and returns to education in Norway; Jensen (2010) uses a survey data for eighth-grade boys in the Dominican Republic and find that the perceived returns to secondary school are extremely low, despite high measured returns; Fan et al. (2015), and Heckman and Li (2004) examine the returns to education in China; Orazem and Vodopivec (1995) analyze the returns to education, experience and gender in Slovenia; Blundell et al. (2000) examine the returns to higher education in Britain; and, finally, Cavaille and Marshall (2019) analyze the returns to education in Western Europe.

Regarding investigations on sociocultural factors that may influence on wage gains, we emphasize that the wage gap between men and women ns Spain is still distant according to Conde-Ruiz y Artiñano (2016). These authors find that the average wage of Spanish men is 14 Euros per hour, while a Spanish woman is barely 11.9 Euros per hour even though the average schooling level of women is higher than that of man. For the Mexican case, AustriaCarlos et al. (2018) also find significant differences by gender in the marginal rate of return to undergraduate and graduate studies in Mexico. These authors show empirical evidence that 
Mexican students that finish undergraduate and graduate studies get higher returns to education than those of Mexican women. Finally, Kong (2017) studies the determinants of the opportunities of employment of new undergraduates in China and finds, from a sample of new graduates in Beijing, that those from prestigious universities obtain higher initial wages $y$ find jobs faster than those from other universities. The author also finds that undergraduates in humanities and social sciences obtain higher starting wages, and women find jobs faster than men, but they get lower wages.

For the Mexican case, the pioneering research on the rates of return of education is the work from Carnoy (1967) finding very high rates, but his study focuses on a survey conducted in three cities: Mexico, Puebla and Monterrey. Later, Bracho and Zamudio (1994) study the economic returns of schooling in Mexico, based on the National Household Income and Expenditure Survey of 1989. They find positive rates of return of education, similar to those found in others Latin American countries, but smaller compared to the Carnoy's study. Regarding education and migration in Mexico, Albo (2010) finds that $20 \%$ of the people that were born in Mexican territory and have doctoral studies live in the United States. According to their estimates, in the period 1994-2008, Mexico transferred 81 USD billion in education expenses to migrants, before emigrating, which is equivalent to more than half a percentage point of GDP per year.

Later, Zamudio (1995) studies the performance of higher education in Mexico by adjusting for bias with information from ENIGH 1989. The author finds significantly high rates after the adjustment to correct bias. On the other hand, Barceinas (2002) analyzes the private and social returns to education in Mexico based on information from ENIGH 1994 and 1996. The author finds a return of $14 \%$ for men and $15 \%$ for women and higher profitability of high school studies. Recently, Austria-Carlos and Venegas-Martínez (2011) analyze the private returns of higher education with a self-selection correction model by using data from the ENIGH 2006. These authors find positive marginal returns to higher education.

According to the above literature review, most of the authors find empirical evidence of positive returns. However, coverage, quality, and levels of education of the heads of family needs to be studied more carefully since it may constitute one of the determinants for increasing the human capital necessary for sustained growth, which, in turn, improves social integration and provides better stages of development. As pointed before, this paper focuses on examining the returns to education of the heads of family by levels of schooling in Mexico in 2016.

\section{Data description}

The National Household Income Survey (ENIGH) has been conducted since 1984, with a biennial periodicity, with the aim of providing a statistical overview of the behavior of household income and expenditure in terms of amount, origin and distribution. It also offers information on the occupational and socio-demographic characteristics of the family members, as well as the characteristics of the housing. The ENIGH 2016 estimates that Mexican population reached 122, 643890 inhabitants, 51.6\% are women and 48.4\% are men. The number of families is 33,462598 , and the average size of the family is 3.67 members. A sample of 65535 families is selected for this research, which provides a $90 \%$ confidence level. In what follows, we present the variables that will be used in this research.

The ENIGH identifies the income as the total of earnings, transfers, rents and another income of each of the family members and is reported on a quarterly basis. In our sample $73 \%$ of the heads of family surveyed are men and $27 \%$ are women. Age, literacy and schooling are 
the main variables of this research. 1 The hours worked is the time in annual hours reported by the ENIGH on a weekly basis. The information of the heads of family was obtained from 65 , 535 people of the Mexican population. The average age of the heads of family is 49.2 years. The descriptive statistics of the main variables are shown in Table 1.

Table 1. Descriptive statistics of the main variables

\begin{tabular}{lllll}
\hline Variables & Average & Stand. dev. & Minimum & Maximum \\
\hline Annual income & 170545.64 & 654899.1 & 0 & $1.43 \mathrm{e}+08$ \\
\hline Schooling & 5.48 & 2.54 & 1 & 11 \\
\hline Experience & 43.42 & 17 & 9 & 93 \\
\hline Hours worked & 2161.12 & 1047.28 & 0 & 320 \\
\hline Number of Observations & 65,535 & & & \\
\hline
\end{tabular}

Source: Own elaboration with data from ENIGH 2016.

Table 1 shows that the average income of the heads of families is 170545.64 Mexican pesos per year in 2016, with a standard deviation of 654899.1 pesos, a maximum income of $1.43 \mathrm{e}+08$ pesos per year and, on average, the heads of family work 2161.12 hours per year. The average level of studies is 5.48, which means that the heads of families study on average up to secondary school; see Figure 1.

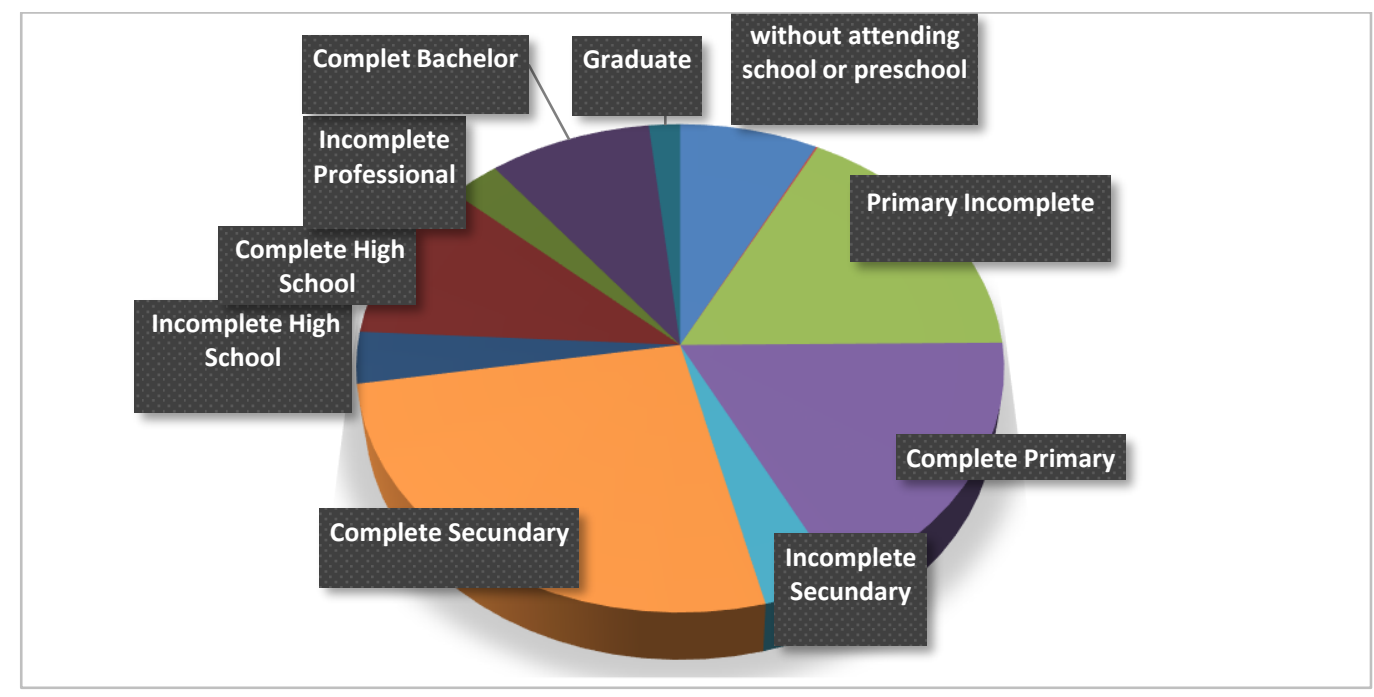

Figure 1. Schooling of family heads

Source: Authors' own elaboration with data from ENIGH 2016.

The previous graph indicates that $7 \%$ of family heads in Mexico have not attended school (without instruction), 17\% did not finish primary school, 18\% have primary school, 4\% did not finish secondary, 26\% have secondary education, 3\% did not finish high school, $11 \%$ finished high school, $3 \%$ did not complete professional education, $9 \%$ have professional studies and $2 \%$ of the population has graduate studies. On the other hand, $42 \%$ of the heads of

\footnotetext{
${ }^{1}$ For the purposes of the research, the levels of schooling of heads of families are classified into 11 levels: 1 without instruction, 2 Preschool, 3 with incomplete primary education, 4 with complete primary education, 5 with incomplete secondary education, 6 with full secondary studies, 7 with incomplete high school studies, 8 with full high school studies, 9 with incomplete professional studies, 10 with full professional studies, 11 with postgraduate studies.
} 
family have primary education, $72 \%$ have secondary school, and $86 \%$ have high school studies. Only $11 \%$ of family heads have professional and graduate studies.

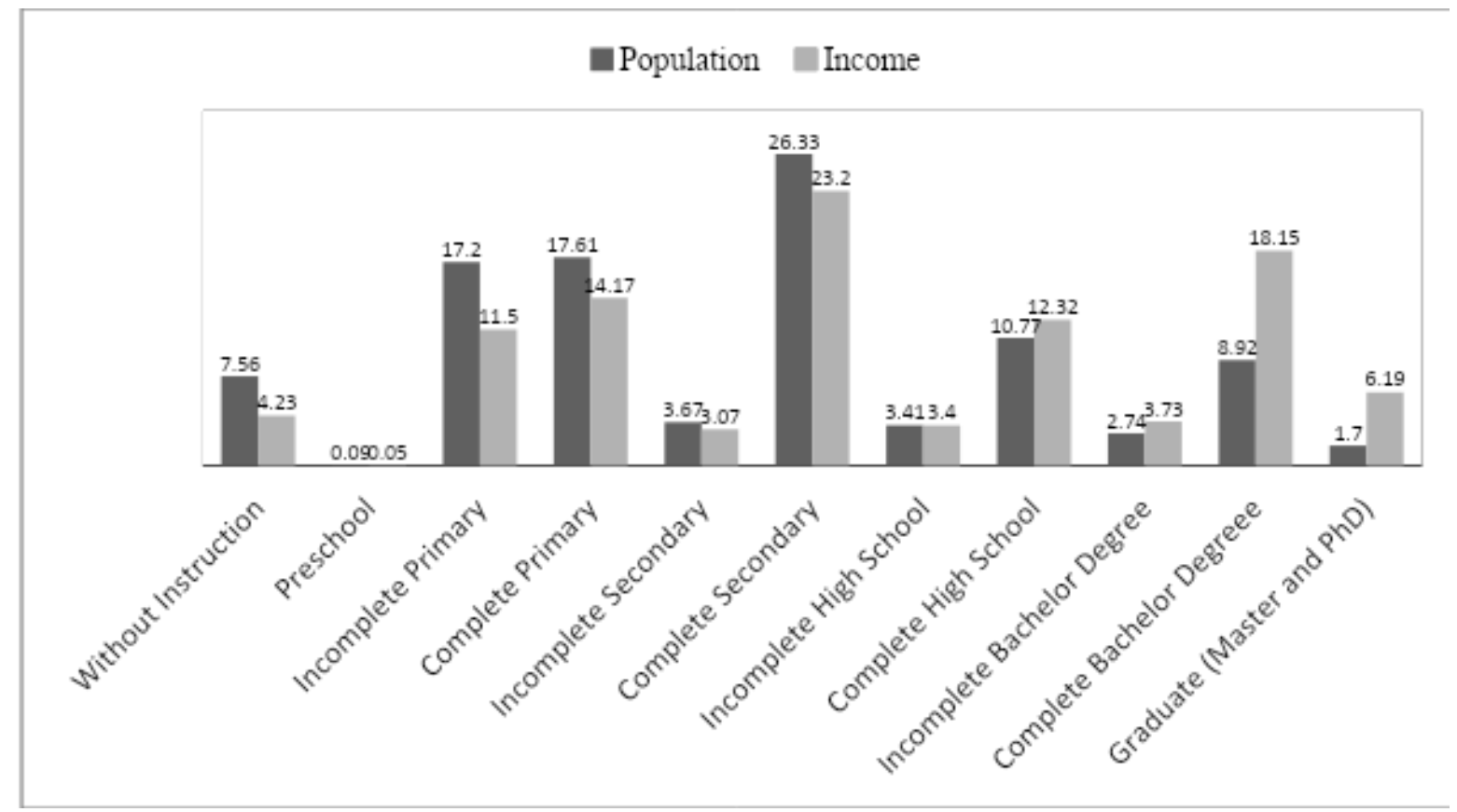

Figure 2. Schooling of the heads of family, population proportion, and participation in income Source: Own elaboration with data from ENIGH 2016.

Figure 2 shows the proportion of the population and the share of total income of the heads of family. It is observed that the heads of families without education represent $7.56 \%$ of the total population and hold $4.23 \%$ of total income. The heads of family with preschool education represent $0.09 \%$ of the population and hold 0.05 of total income. Heads of family with incomplete primary education represent $17.2 \%$ of the population and hold $11.5 \%$ of total income. Heads of family that finished primary represent $17.61 \%$ of the population and have $14.17 \%$ of total income. Heads of family that did not finish secondary represent $3.67 \%$ of the population and have $3.07 \%$ of the total income; while heads of family that finished secondary represent $26.33 \%$ of the population and have $23.20 \%$ of the income.

Heads of families with incomplete high school represent $3.41 \%$ of the population and hold $3.40 \%$ of total income; while heads of families with full high school represent $10.77 \%$ of the population and have $12.32 \%$ of total income. Heads of families with incomplete professional studies represent $2.74 \%$ of the population and $3.73 \%$ of the income; while parents with full professional studies represent $8.92 \%$ of the population and $18.15 \%$ of the income. The heads of family with postgraduate studies stand for $1.70 \%$ of the population and correspond to $6.19 \%$ of total income. Also, $24.85 \%$ of the heads of family that have not finished primary correspond to $15.78 \%$ of total income. The heads of family that have professional and graduate studies represent $10.62 \%$ of the population and hold $24.34 \%$ of total income.

\section{Mincer equation estimation}

Based on the National Household Income Survey of 2016, the results presented in this section can be useful for decision-making in public policy and for planning public and private education in Mexico. To estimate, first, the returns to education of the heads of family in 
Mexico, the simple Mincerian equation (1), which relates the logarithm of income to education, the experience, and the square of the experience will be used. The results from the estimation appear in Table 2.

Table 2. Mincer Earnings Equation

\begin{tabular}{lc}
\hline Independent variables & Coefficient \\
\hline Constant & $9.958748^{*}$ \\
\hline Schooling & $0.1565517^{*}$ \\
\hline Experience & $0.0338553^{*}$ \\
\hline Squared Experience & $-0.000287^{*}$ \\
\hline Logarithm of hours & $0.0062417^{* *}$ \\
\hline Dependent Variable: logarithm of income & \\
\hline
\end{tabular}

Source: own elaboration with data of the ENIGH 2016

$*[P(t)$ significat at $1 \%], * *[P(t)$ significat at $10 \%]$

Number of observations: 65,535 .

The estimated coefficients of the contributions of schooling, experience, hours worked, and income are positive, while the square of experience is negative; all of them have the appropriate signs and are significant. The profitability of education is $15.65 \%$ per year by level of studies of the heads of the family. The coefficient presents a positive sign, which implies that as the level of schooling increases, the income of the heads of family increases. The variation in the income of employees is also explained, but in a lesser proportion by experience around 3\%, the square experience has an expected negative sign, hours worked has a positive coefficient of $0.6 \%$, although it is not relevant in the variations in income.

The obtained results are consistent with previous studies for Mexico. Zamudio and Bracho (1994) find yields of the order of $11.8 \%$ for Mexico, Barceinas (2002) estimated rates of return of the order of $9 \%$ for Spain. Subsequently, the returns to education in Mexico are estimated with dummy variables and the results are presented in Table 3.

Table 3. Annual income level in MXP and USD

\begin{tabular}{lcl}
\hline Level of Schooling & $\begin{array}{l}\text { Average per person in } \\
\text { MXP }\end{array}$ & $\begin{array}{l}\text { Average per person } \\
\text { USD }\end{array}$ \\
\hline Without instruction & $52906.80^{*}$ & 2565.87 \\
\hline Preeschoolar & $62648.04^{*}$ & 3038.30 \\
\hline Incomplete Primary & $99079.92^{*}$ & 4805.18 \\
\hline Complete Primary & $132512.16^{*}$ & 6426.58 \\
\hline Incomplete Secundary & $139921.08^{*}$ & 6785.89 \\
\hline Complete Secundary & $153101.16^{*}$ & 7425.10 \\
\hline Incomplete High School & $172578.60^{*}$ & 8369.72 \\
\hline Complete High School & $193676.76^{*}$ & 9392.94 \\
\hline Incomplete Professional & $224295.00^{*}$ & 10877.8 \\
Complete Professional & $279656.28^{*}$ & 13562.77 \\
Graduate & $356689.08^{*}$ & 17298.71 \\
\hline
\end{tabular}

Dependent variable: annual income

Source: own elaboration with data from the 2016 ENIGH and BANXICO.

$*[P(t)$ significative at $1 \%]$ Number of observations: 65,535 . 
Table 3 shows that the average annual income of a family head without studies is USD 2565.87; with preschool average income is USD 3038.30 per year; with incomplete primary average income is USD 4805.18, while with complete primary is 6426.58 USD per year; with incomplete secondary school average income is 6785.89 USD per year; with incomplete high school the average income is 8369.72 USD, while with full high school is 9392.94 USD per year; with incomplete bachelor degree average income is 10877.8 USD per year, while with complete bachelor degree is 13562.77 USD per year. The heads of family with graduate studies have an average income of USD 17,298 per year. In summary, an increase in the average formal education level has a positive impact on income of family heads in Mexico.

\section{Conclusion}

We have estimated the returns to education of family heads in Mexico in 2016 based on the information from the National Household Income Survey for 2016, which is provided by the Mexican National Institute of Statistics, Geography and Information, In this research, we reviewed briefly the literature that addresses the returns to education, whose consensus is that an increase in the level of schooling has a positive impact on income. Subsequently, the data, the source of information and the descriptive statistics of the main variables were presented. The descriptive statistics analysis indicates that the education of the heads of family has a positive relationship with their income. The main empirical results from the estimation of Mincer's (1974) equation shows positive signs for the returns to education of the heads of family in Mexico in 2016, schooling has returns of $15.65 \%$ per year corresponding to each level of studies, while the experience is 3\% and the hours worked of $0.6 \%$. Finally, the returns of the education of heads of family are estimated by level of studies with variable dummies in order to find the returns for each level of schooling. The overall conclusion is that as the level of education increases, it magnifies the increase in income levels, which, in turn, increases human capital and learning capacity needed for sustained growth and welfare.

\section{References}

Aali-Bujari, A., Ortiz-Zarco, R. y Ríos-Bolívar, H. (2013). Rendimientos educativos en México, 2010. Un análisis empírico. Tiempo Económico, 8(23), 52-60.

Albo (2010). Situación Migración México. Servicios de Estudios Económicos Fundación BBVA Bancomer, 1-60.

Arild, A., Salvanes, K. G., \& Vaage, K. (2010). Measuring heterogeneity in the returns to education using an education reform. European Economic Review, 54(4), 483-500.

Austria-Carlos, M. A. y Venegas-Martínez, F. (2017). Impacto del gasto en educación y salud de los hogares en el ingreso de los individuos que concluyeron una licenciatura o posgrado en México. Revista Nicolaita de Estudios Económicos, 12(1), 79-105.

Austria-Carlos, M. y Venegas-Martínez, F. (2011). Rendimientos privados de la educación superior en México, 2006. Un modelo de corrección del sesgo por autoselección. Trimestre Económico, 78(2), 441-468.

Austria-Carlos, M., Venegas-Martínez, F., \& Pérez-Lechuga, G. (2018). Differences by gender in the marginal rate of return to undergraduate and graduate studies in Mexico. Papeles de Población, 24(96), 157-186.

Barceinas, F. (2002). Rendimientos privados y sociales de la educación en México. Economía Mexicana. Nueva Época, 11(2), 333-390. 
Becker, G. (1975). Human capital: theoretical and empirical analysis, with special reference to education. In NBER Books from National Bureau of Economic Research, New York.

Benavot, A. (1989). Education, gender, and economic development: A cross-national study. Sociology of Education, 62(1), 14-32.

Blanden, J. (2013). Cross-country rankings in intergenerational mobility: a comparison of approaches from economics and sociology. Journal of Economic Surveys, 27(1), 38-73.

Blundell, R., Dearden, L., Goodman, A., \& Reed, H. (2000). The returns to higher education in Britain: evidence from a British cohort. The Economic Journal, 110(461), F82-F99,

Blundell, R., Dearden, L., Meghir, C., \& Sianesi, B. (1999). Human capital investment: The returns from education and training to the individual, the firm and the economy. Fiscal Studies, 20(1), 1-23.

Bracho, T. y Zamudio, A. (1994). Los rendimientos económicos de la escolaridad en México, 1989. Economía Mexicana. Nueva Época, 3(2), 345-377.

Carneiro, P., Heckman, J. J., \& Vytlacil, E. J. (2011). Estimating marginal returns to education. American Economic Review, 101(6), 2754-2781.

Carnoy, M. (1967). Earnings and schooling in Mexico. Economic Development and Cultural Change, 15(4), 408-419.

Cavaille, C. \& Marshall, J. (2019). Education and anti-immigration attitudes: evidence from compulsory schooling reforms across Western Europe. American Political Science Review, 113(1), 254-263.

Cellini, S. \& Chaudhary, L. (2014). The labor market returns to a for-profit college education. Economics of Education Review, 43(C), 125-140.

Christiansen, C., Joensen, J., \& Nielsen, H. (2007). The risk-return trade-off in human capital investment. Labour Economics, 14(6), 971-986.

Conde-Ruiz, I. y Artiñano, I. (2016). Brechas salariales de género en España. ZOOMEconómico, 9, 1-27.

Denice, P. (2015). Does it pay to attend a for-profit college? Vertical and horizontal stratification in higher education. Social Science Research, 52, 161-178.

Doyle, W. \& Skinner, B. (2016). Estimating the education-earnings equation using geographic variation. Economics of Education Review, 53(C), 254-267.

Fan, W., Ma, Y., \& Wang, L. (2015). Do we need more public investment in higher education? Estimating the external returns to higher education in China. Asian Economic Papers, 14(3), 88-104.

Fogarty, C. \& Hasegawa, R. (2019). Extended sensitivity analysis for heterogeneous unmeasured confounding with an application to sibling studies of returns to education. The Annals of Applied Statistics, 13(2), 767-797.

Frankema, E. \& Bolt, J. (2006). Measuring and analysing educational inequality: The distribution of grade enrolment rates in Latin America and Sub-Saharan Africa. Research Memorandum GD-86, University of Groningen, Netherland.

Giannelli, G. \& Monfardini, C. (2003). Joint decisions on household membership and human capital accumulation of youths. The role of expected earnings and local markets. Journal of Population Economics, 16(2), 265-285.

Griliches, Z. (1977). Estimating the returns to schooling: some econometric problems. Econometrica, 45(1), 1-22.

Heckman, J. (2005). China's human capital investment. China Economic Review, 16(1), 5070.

Heckman, J. J. \& Li, X. (2004). Selection bias, comparative advantage and heterogeneous returns to education: evidence from China in 2000. Pacific Economic Review, 9(3), 155171. 
Hout, M. (2012). Social and economic returns to college education in the United States. Annual Review of Sociology, 38(1), 379-400.

Hugget, M., Ventura, G., \& Yaron, A. (2006). Human capital and earnings distribution dynamics. Journal of Monetary Economics, 53(2), 265-290.

Jensen, R. (2010). The (perceived) returns to education and the demand for schooling. Quarterly Journal of Economics, 125(2), 515-548.

Kong, J.(2017). Determinants of graduates' job opportunities and initial wages in China. Intenational Labour Review, 136(1), 99-113.

Mincer, J. (1974). Schooling, experience and earnings. NBER Working Paper 0053, National Bureau of Economic Research, Inc. New York.

Nafukho, F., Haireston, N., \& Brooks, K. (2004). Human capital theory: implication for human resource development. Perspective on Research, 7(4), 545-551.

Orazem, P. F. \& Vodopivec, M. (1995). Winners and losers in transition: returns to education, experience, and gender in Slovenia. World Bank Economic Review, 9(2), 201-230,

Oreopoulos, P. \& Petronijevic, U. (2013). Making college worth it: a review of research on the returns to higher education. National Bureau of Economic Research (NBER). Working Paper No. 19053.

Psacharopoulos, G. (1989). Time Trends of the Returns to Education: Cross-National Evidence. Economics of Education Review, 8(3), 225-231.

Psacharopoulos, G. (1994). Returns to investment in education: A global update. World Development, 22(9), 1325-1343.

Psacharopoulos, G. \& Patrinos, H. (2004). Returns to investment in education: a further update. Education Economics, 12(2), 111-134.

Schultz, T. (1961). Investment in human capital. American Economic Review, 51(1), 1-17.

Su, Y. \& Liu, Z. (2016). The impact of foreign direct investment and human capital on economic growth: evidence from Chinese cities. China Economic Review, 37, 97-109.

Zamudio, A. (1995). Rendimientos a la Educación Superior en México: Ajuste por sesgo utilizando máxima verosimilitud. Economía Mexicana. Nueva Época, 4(1), 69-91. 